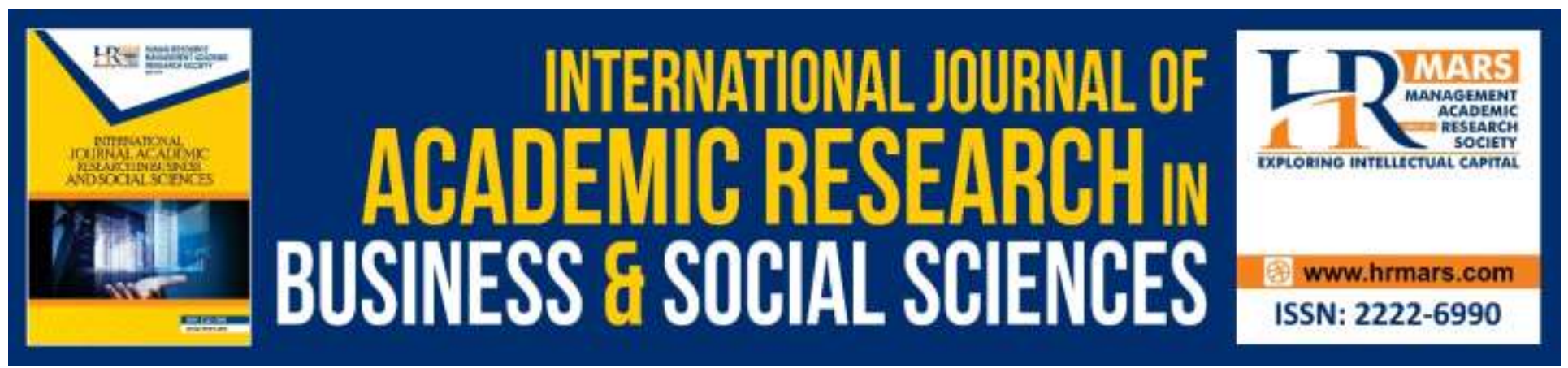

\title{
The Relationship between Internet Usage and Subjective Wellbeing among Youths in Malaysia
}

\author{
Siti Zobidah Omar, Mohd. Fauzi B Fadzil \& Jusang Bolong
}

To Link this Article: http://dx.doi.org/10.6007/IJARBSS/v9-i7/6138

DOI: $10.6007 /$ IJARBSS/v9-i7/6138

Received: 22 May 2019, Revised: 10 June 2019, Accepted: 30 June 2019

Published Online: 21 July 2019

In-Text Citation: (Omar, Fadzil, \& Bolong, 2019)

To Cite this Article: Omar, S. Z., Fadzil, M. F. B., \& Bolong, J. (2019). The Relationship between Internet Usage and Subjective Wellbeing among Youths in Malaysia. International Journal of Academic Research in Business and Social Sciences, 9(7), 461-469.

Copyright: (C) 2019 The Author(s)

Published by Human Resource Management Academic Research Society (www.hrmars.com)

This article is published under the Creative Commons Attribution (CC BY 4.0) license. Anyone may reproduce, distribute, translate and create derivative works of this article (for both commercial and non-commercial purposes), subject to full attribution to the original publication and authors. The full terms of this license may be seen

at: http://creativecommons.org/licences/by/4.0/legalcode

Vol. 9, No. 7, 2019, Pg. 461 - 469

http://hrmars.com/index.php/pages/detail/IJARBSS

JOURNAL HOMEPAGE

Full Terms \& Conditions of access and use can be found at http://hrmars.com/index.php/pages/detail/publication-ethics 


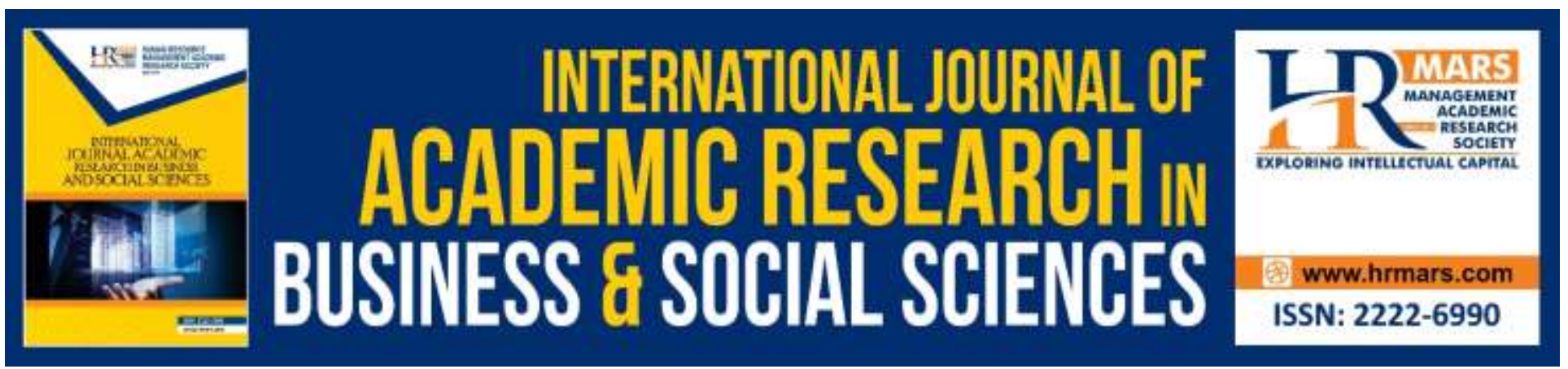

\title{
The Relationship between Internet Usage and Subjective Wellbeing among Youths in Malaysia
}

\author{
1,2Siti Zobidah Omar, ${ }^{1}$ Mohd. Fauzi B Fadzil \& ${ }^{1,2}$ Jusang Bolong \\ ${ }^{1}$ Institute for Social Science Studies, Universiti Putra Malaysia, ${ }^{2}$ Faculty of Modern Language and \\ Communication, Universiti Putra Malaysia
}

\begin{abstract}
The objective for this study is to examine the relationship between internet usage and subjective wellbeing (using a Scale of Positive and Negative Experience or SPANE) among multiracial youths in Malaysia. This study attempts to close the gap between practice and research that focuses on internet usage and Malaysian youth wellbeing. The study uses a quantitative approach (cross sectional survey) whereby 400 youths across four zones in Malaysia were selected as respondents. Based on the aim of this study, it was found that all three factors studied which is psychology and family relationship wellbeing; leisure and health wellbeing and; socio-economic wellbeing are significantly related to positive feelings but none of them yield significant results with negative feelings. The study stresses on the need for parents to advocate their children on the proper use of internet, especially youths in the age of 15 to 25 .
\end{abstract}

Keywords: Subjective Wellbeing, Internet, Youth, SPANE, Malaysia.

\section{Introduction}

Drawing on Joorabchi et al. (2013)'s study on internet usage, youths are found to be active internet users in Malaysia. Their study claimed that 35.2\% of Malaysian youths spent about 24 to 63 hours using the internet in a week (about 3.5 to 9 hours per day). This claim is further backed up by the Malaysian Communications and Multimedia Commission or MCMC (2017), they highlighted that $53.6 \%$ of youths aged between 20 to 34 years old spent more time on the internet compared to $35.1 \%$ of adults in Malaysia aged between 50 to 64 years old.

Frequent internet usage doubtlessly does have positive impacts on youth's socio-economic routines; nevertheless, it also comes with several negative impacts. There are several opinions among scholars regarding the impact of internet usage upon youth's wellbeing. Scholars such as Guan and Subrahmanyam (2009) claimed that internet usage will increase emotional wellbeing; similarly, Du Rausas et al. (2011) also confirmed that internet usage have positively impacted economic wellbeing. Comparatively, Kraut et al. (2002) found that internet usage actually have negative impacts on social wellbeing. Inconsistencies from past findings have raised a question - what is the impact of internet 
usage among youths in Malaysia, does it affect them positively or negatively? This question is the gap that didn't been answered yet in youth contextual wellbeing, the usage of Scale of Positive and Negative Experience (SPANE) in answering those question is also considered as development of theoretical gap in youth wellbeing. The research question has led the study to its main objective; to measure the impact of internet usage on Malaysian youths' subjective wellbeing.

\section{Internet Usage among Youths in Malaysia}

According to the Akta Pertubuhan Belia Dan Pembangunan Belia (2007), Malaysian youth is defined as individuals in the age of 15 to 40 years old. Data from MCMC have stated that there are $76.9 \%$ of internet users in Malaysia, which is about 24.5 million of people within the Malaysian population (Malaysian Communications and Multimedia Commission, 2017). The data clearly stated that the adoption rate of internet usage was negatively correlated with age, which insinuated that the majority of internet users in Malaysia came from younger age groups. Youths especially, make up about $50.7 \%$ out of the total internet users in Malaysia.

Malaysian youths are known to be mobile-oriented and the majority of them are compatible users of smartphones when it comes to accessing the internet compared to other devices such as netbook, desktop, or tablet. This assertion is proven through the MCMC (2017) report that accessing the internet from other devices saw a declining trend among Malaysian youths. This particular age group felt comfortable accessing the internet when they are at home, work, and also places that provide free Wi-Fi such as cybercafés. Usually, Malaysian youths used the internet for two main reasons; texting and visiting social networking sites, Facebook was the most preferable social networking site for socializing. Youth is known to be an age group that constantly needs to explore their identity, hence they feel the need to frequently communicate with the people around them in order to socially identify them and in this case the internet helps them overcome the gap. Internet usage among Malaysian youths have also led to cybercrime although the ratio was relatively low, this is due to the inspection made under the Computer Crime Act 1997 (Appudurai \& Ramalingam, 2007).

\section{Subjective Wellbeing among Youths in Malaysia}

Since the 1950's until today, the Malaysian government measures the society's wellbeing objectively by assessing the Malaysian community's wellbeing based on their economic level which also known as objective wellbeing. It is also understood that objective wellbeing can be measured using Gross Domestic Product (GDP) or also known as economic growth measuring tool. This type of measurement looks into the society's income and ownership, which provides information regarding Malaysian youths' assets and buying power. Such objective measures can be interpreted as the society's buying power whereby an increase GDP equals to higher individual purchase power. Overall, individual wellbeing cannot be measured solely on objective components, the subjective components also influence the individual's wellbeing. The concept of subjective wellbeing differs from objective wellbeing (quantitative in nature) whereby subjective measurement includes the social and cultural aspects of the individual's wellbeing (M. Yassin et al., 2015). Subjective wellbeing can be understood as the consciously valued assessment of an individual based on their psycho-bio, political-socioeconomic, and physical environment which involves opinion regarding the person's adequacy, 
INTERNATIONAL JOURNAL OF ACADEMIC RESEARCH IN BUSINESS AND SOCIAL SCIENCES Vol. 9, No. 7, July, 2019, E-ISSN: 2222-6990 @ 2019 HRMARS

satisfaction, favorite, comfort and enjoyment on their job, culture, economy, physical accommodation, public safety, and humanitarian relationship (qualitative in nature). Subjective wellbeing also justifies that the measurement of economical assessment (objective wellbeing) is insufficient because it does not provide a true meaning of individual wellbeing; sometimes an increment of wealth or asset will mortgage safety, health or inequality. In this situation, how can mortgage-backed securities determine a person's wellbeing? This is where subjective wellbeing fills the gap by including three indicators adopted from M. Yassin et al.'s study (2018). The three indicators of subjective wellbeing for this study are socio-economic wellbeing, psychology and family relationships wellbeing, and health and leisure time wellbeing.

This research assesses subjective wellbeing using the SPANE, this scale is an instrument that assesses subjective feelings of wellbeing and ill-being. Based on findings by Bradburn (1969), it was found that there are two separate components of subjective wellbeing; positive effects and negative effects, SPANE then define these two components as pleasant/ positive feelings and unpleasant emotions/ negative feelings (Li et al., 2013). The SPANE instrument consists of twelve items; 6 positive feelings and 6 negative feelings (Diener et al., 2010). For this research specifically, all SPANE items are based on feeling of Positive, Negative, Good, Bad, Pleasant, Unpleasant, Happy, Sad, Afraid, Joyful, Angry, and Contented. All 12 items will then be tested on its correlation with subjective wellbeing (socioeconomic wellbeing, psychology and family relationships wellbeing, and health and leisure time wellbeing). The established correlation can determine the level of Malaysian youths' subjective wellbeing regarding their internet usage. Up to date, no research has been done on Malaysian youths' subjective wellbeing (Yassin et al., 2015). The current research can be considered as a pioneer study to fill this gap.

\section{Methodology}

This research uses a cross sectional survey. This method was choose because it can be used to prove or disprove assumptions. As been discusses before in the introduction, there are two assumption about internet usage on youth wellbeing. Using this method in this study, those assumption can be prove or disprove. This method also can help addressing the research objective by proving the impact of internet usage upon youth wellbeing, either it is giving positive or negative impact. The survey consists of sections divided based on the demographic data of respondents, and the impact of internet usage on Malaysian youths' subjective wellbeing. To ensure its validity and reliability, the instrument went through several processes; namely, i) literature review and document analysis; ii) workshop for instrument consolidation; and iii) pilot study and; iv) as the validation process to solidify the instrument. A multi-stage random sampling was applied during the study's sampling process, which started with a cluster random sampling. Four zones in Malaysia were selected in this study; northern zone, southern zone, east coast zone, and Sabah/Sarawak zone. Each zone was represented by a state that was selected randomly (Kedah, Johor, Terengganu, and Sabah). After the states were selected randomly, a district was also chosen randomly for the data collection process. Subsequently, a total of 100 youths under the selected districts were chosen as respondents (100 respondent $x 4$ zones $=400$ respondents). In the second phase of the sampling process, a stratified random sampling was applied to ensure that the chosen respondents actually represent the ethnic groups in Malaysia. 
INTERNATIONAL JOURNAL OF ACADEMIC RESEARCH IN BUSINESS AND SOCIAL SCIENCES Vol. 9, No. 7, July, 2019, E-ISSN: 2222-6990 @ 2019 HRMARS

According to the Department of Statistics Malaysia (2015), the latest percentage of ethnic groups in Malaysia shows that there are 56\% Malays, 24\% Chinese, 13\% Bumiputera Sabah/Sarawak, and 7\% Indians. This percentage obliges about 280 Malay, 120 Chinese, 65 Bumiputera Sabah/ Sarawak, and 35 Indian respondents to make up the total sampling population. The data collection process was assisted by trained and experienced enumerators. The data collection processes were monitored by research team members. To answer this study's objective, the data were then analyzed using a Pearson product moment correlation.

\section{Result}

Table 1 demonstrates the demographic data of Malaysian youths' internet usage. About $41.3 \%$ of the respondents were between the age of 21-25 years old, the rest are below 20 years old (26.5\%), 2630 years old $(16.8 \%)$ and above 31 years old (15.5\%). The data shows that $66.5 \%$ of them are female and the majority of active internet users were among the Malays (55.5\%). More than half of them (56\%) passed the tertiary level of education and most of them (42.3\%) have around 4-5 household members. Furthermore, more than half of them (54\%) hold a permanent job status while the other $55.4 \%$ have income of more than RM 1000.00 per month. The majority of these respondents have lived in their resided area for more than 21 years (38.3\%), whereas the rest lived in their resided area for less than 20 years.

\begin{tabular}{|l|l|l|l|}
\hline Factors & Frequency & Percentage & Mean score \\
\hline Age (years) & & & 24.5 \\
\hline$<20$ & 106 & 26.5 & \\
\hline $21-25$ & 165 & 41.3 & \\
\hline $26-30$ & 67 & 16.8 & \\
\hline$>31$ & 62 & 15.5 & \\
\hline & & & \\
\hline Gender & & & \\
\hline Male & 134 & 33.5 & \\
\hline Female & 266 & 66.5 & \\
\hline & & & \\
\hline Races & & & \\
\hline Malay & 222 & 55.5 & \\
\hline Chinese & 94 & 23.5 & \\
\hline Indian & 28 & 7.0 & \\
\hline Sabahan & 28 & 7.0 & \\
\hline Sarawakian & 28 & 7.0 & \\
\hline & & & \\
\hline Education level & & & \\
\hline Never been to school & 1 & .3 & \\
\hline Primary school & 8 & 2.0 & \\
\hline Lower secondary school & 9 & 2.3 & \\
\hline
\end{tabular}


INTERNATIONAL JOURNAL OF ACADEMIC RESEARCH IN BUSINESS AND SOCIAL SCIENCES Vol. 9, No. 7, July, 2019, E-ISSN: 2222-6990 @ 2019 HRMARS

\begin{tabular}{|l|l|l|l|}
\hline Upper secondary school & 158 & 39.5 & \\
\hline Tertiary & 224 & 56.0 & \\
\hline Number of household members & & & \\
\hline 3 or less & 103 & 25.8 & \\
\hline $4-5$ & 169 & 42.3 & \\
\hline 6 or more & 128 & 32.0 & \\
\hline & & & \\
\hline Job status & & & \\
\hline Permanent & 216 & 54.0 & \\
\hline Contract & 74 & 18.5 & \\
\hline Self-employed & 35 & 8.8 & \\
\hline Unemployed & 75 & 18.8 & \\
\hline & & & \\
\hline Income per month $(\mathrm{n}=325)$ & & & \\
\hline$<$ RM1000 & 180 & 55.4 & \\
\hline$>$ RM1001 & 145 & 44.6 & \\
\hline & & & \\
\hline Duration of staying in the area (years) & & 33.0 & \\
\hline 10 or less & 132 & 28.8 & \\
\hline $11-20$ & 115 & 38.3 & \\
\hline 21 or more & 153 & & \\
\hline
\end{tabular}

Table 1: Demographic Of Youth Internet User In Malaysia

The resulted findings demonstrated that all factors recorded a positive and significant relationship with positive feelings. The psychological and family relationship wellbeing factor recorded a significant and moderate level of relationship with wellbeing $(r=.577, p=.0001)$, the leisure and health wellbeing factor recorded a positive and moderate relationship with wellbeing $(r=.607, p=$ .0001), and the socio-economic factor recorded a significant and moderate relationship with wellbeing $(r=.665, p=.0001)$.

\begin{tabular}{|l|l|l|}
\hline Factors & $r$ & $p$ \\
\hline Psychology and family relationship wellbeing & .577 & .0001 \\
\hline Leisure and health wellbeing & .607 & .0001 \\
\hline Socio-economic wellbeing & .665 & .0001 \\
\hline
\end{tabular}

Table 2: Relationship between internet well-being and positive feelings

Guilford Rule of Thumb ( $r$ )

0.90 to 1.00 (very high),

0.70 to 0.90 (high),

0.50 to 0.70 (moderate),

0.30 to 0.50 (low) 
INTERNATIONAL JOURNAL OF ACADEMIC RESEARCH IN BUSINESS AND SOCIAL SCIENCES

Vol. 9, No. 7, July, 2019, E-ISSN: 2222-6990 @ 2019 HRMARS

0.00 to 0.30 (little)

This study found that all subjective wellbeing indicators have an insignificant $p$ value between negative feelings of SPANE and internet wellbeing. Based on the recorded $r$ and $p$ value, none of the factors under negative feelings recorded a significant relationship with internet well-being.

\begin{tabular}{|l|l|l|}
\hline Factors & $r$ & $p$ \\
\hline Psychology and family relationship well-being & .068 & .174 \\
\hline Leisure and health well-being & .096 & .055 \\
\hline Socio-economic well-being & -.030 & .549 \\
\hline
\end{tabular}

Table 3: Relationship between internet well-being and negative feelings

\section{Discussion}

This research displays an overview of the respondents' internet wellbeing and SPANE, this research found that the principle idea of internet usage among the respondents revolve around social relationship. Based on this social relationship ground, it expanded towards the economic and political aspects of wellbeing. According to the MCMC (2017), the highest online activities among internet user in Malaysia (including youth) is to communicate by text (96.3\%), to get information via internet (86.9\%), and to do online shopping (48.8\%). Most youths in Malaysia uses the internet to maintain their social relationship with family members and close friends, which is why their main purpose of internet usage was related to sustaining social relationships. According to Chen \& Katz (2009), mobile phones were often used by youths as a communication tool to connect with family members and friends. This particular age group enjoy calling and texting their family and friends as a mean of escape from something distressful and seek enjoyment (Jin \& Park, 2010). Other than fulfilling the need to sustain their social relationships, these youths will spend their time on the internet for online shopping and political news.

Looking at the data from this research, it is concluded that the frequent internet usage among youths in Malaysia can lead to their subjective wellbeing. Every relationship related to positive feelings yielded moderate scores compared to negative feelings. It has been proven that internet usage can provide online therapeutic treatment for a range of mental health disorders including depression, anxiety, and addiction. It was also reported that a moderate use of online communication can benefit a person's wellbeing (Jones, 2011). The problem will eventually arise if the use of internet heightens, which may lead to internet addiction.

Generally, there are rooms for improvement to further strengthen the use of internet and its impact on the subjective wellbeing among youths in Malaysia. Internet usage may have several advantages, this includes building a name or identity for oneself like being instafamous. This kind of phenomenon can profit and widen the social network for youths, but if this situation is not monitored then it can possibly cause mental illness and deteriorate physical health of both the individual and the entire society (Lanaj et al., 2014) 


\section{Recommendations and Conclusion}

This study have found that usage of internet among youth can developed positive feeling, but the usage must be control to avoid addiction. This is why the discipline of internet usage must be nurtured starting from young age. As been told before, youths in Malaysia are considered as individuals in age of 15 to 40 years old in Malaysia. It is difficult to control middle-aged youths because most of them live independently from family, but it is not too late to educate youths who are below 25 years old through parental control. Study by Lim and Soon (2009) shows that youth can perform well in their education and still have time for the internet if the mothers pay attention to how they oversee their children's internet use. The mothers must be creative in deploying internet usage by coordinating schedules in the course of discipline and monitoring their children. In conclusion, the internet should be 'weapon' for parents to promote wellbeing among youths and its usage should not be treated otherwise.

\section{References}

Belia, A. P. B. D. P. (2007). Retrieve from http://www.ippbm.gov.my/dokumen/akta-pertubuhanbelia-dan-pembangunan-belia-2007.pdf.

Appudurai, J. \& Ramalingam, C. L. (2007). Computer Crimes: A Case Study of What Malaysia Can Learn from Others? Journal of Digital Forensics, Security and Law: Vol. 2, No. 2, Article 1, Pages 721.

Bradburn, N. M. (1969). The Structure of Psychological Well-being. Oxford England: Aldine.

Chen, Y. F \& Katz, J. E. (2009). Extending Family to School Life: College Students' Use of the Mobile Phone. International Journal of Human-Computer Studies, Volume 67, Pages 179-191.

Department of Statistics Malaysia. (2015). Population \& Demography. Taken on 6 December 2018, retrieved from

https://www.dosm.gov.my/v1/index.php?r=column/ctwoByCat\&parent_id=115\&menu_id=LOpheU 43NWJwRWVSZkIWdzQ4TIhUUT09.

Rausas, D. M. P., Manyika, J., Hazan, E., Bughin, J., Chui, M. \& Said, R. (2011). Internet Matters: The Net's Sweeping Impact on Growth, Jobs and Prosperity. McKinsey Global Institute.

Guan, S. A. \& Subrahmanyam, K. (2009). Youth Internet use: Risks and Opportunities. Curr. Opin. Psychiatry, Vol. 22, Pages 351-356.

Jin, B. \& Park, N. (2010). In-Person Contact Begets Calling and Texting: Interpersonal Motives for Cell Phone Use, Face-to-Face Interaction, and Loneliness. Cyberpsychology, Behavior And Social Networking, Volume 13, Number 6, Pages 611-618.

Jones, P. H. (2011). The Impact of Digital Technologies on Human Wellbeing: Evidence from the Sciences of Mind and Brain. Oxford: Oxford Science Park.

Joorabchi, T. N., Hassan, M. D. \& Osman, M. N. (2013). Relationship between Internet Usage and Positive Youth Development in Malaysia. The Journal of South East Asia Research Centre for Communication and Humanities, Vol. 5, No. 2, Pages 37-64.

Kraut, R., Kiesler, S., Boneva, B., Cummings, J., Helgeson, V. \& Crawford, A. (2002). Internet Paradox Revisited. Journal of Social Issues, Vol. 58, No. 1, Pages 49-74. 
INTERNATIONAL JOURNAL OF ACADEMIC RESEARCH IN BUSINESS AND SOCIAL SCIENCES

Vol. 9, No. 7, July, 2019, E-ISSN: 2222-6990 ¿ 2019 HRMARS

Lanaj, K., Johnson, R. E., \& Barnes, C. M. (2014). Beginning the Workday Yet Already Depleted? Consequences of Late-night Smartphone Use and Sleep. Organizational Behavior and Human Decision Processes, Volume 124, Issue 1, Pages 11-23.

Li, F., Bai, X. \& Wang Y. (2013). The Scale of Positive and Negative Experience (SPANE): Psychometric Properties and Normative Data in a Large Chinese Sample. PLoS One, Vol. 8, Article 4.

Lim, S. S. \& Soon, C. (2009). The influence of social and cultural factors on mothers' domestication of household ICTs - Experiences of Chinese and Korean women. Telematics and Informatics, Vol. 27, Pages 205-216.

Malaysian Communications and Multimedia Commission. (2017). Internet Users Survey 2017: Statistical Brief Number Twenty-One. Cyberjaya: Malaysian Communications and Multimedia Commission.

Najib, M. A. G. (1999). Penyelidikan Pendidikan. Johor: Penerbit Universiti Teknologi Malaysia.

Yassin, M. S., Samah, A. A., D’Silva, J. L., Shaffril, M. H. A. \& Sahharon, H. (2015). Menjejaki Kesejahteraan Dari Kaca mata Komuniti Malaysia. Cheras: Yayasan Basmi Kemiskinan dengan kerjasama Universiti Putra Malaysia.

Yassin, M. S., Samah, A., D’Silva, J. L., Shaffril, M. H. A. \& Mazuki, R. (2018). Wellbeing: Concept, Index, Measurement \& Policy Implications. Serdang: UPM Press. 